\title{
Validity and Reliability Evaluation of a Scale to Measure the Management of Total Productive Maintenance
}

\author{
G. Andrés Hernández, M. Salvador Noriega, Vianey Torres-Argüelles*, \\ Aurora Irma Máynez Guaderrama, G. Erwin Martínez \\ Department of Industrial and Manufacturing Engineering, Institute of Engineering and Technology, Autonomous \\ University of Ciudad Juárez, Ciudad Juárez, Chih., México; \\ jhernand@uacj.mx,snoriega@uacj.mx,vianey.torres@uacj.mx,amaynez@uacj.mx,emartine@uacj.mx
}

\begin{abstract}
Objectives: To explain the development of a questionnaire for the identification of the Critical Success Factors -CSF- of Total Productive Maintenance from the ample list of factors cited in the literature. Methods/Statistical Analysis: The questionnaire is constructed with the factors determined in the literature. The common method bias was discarded and several confirmatory analyses procedures tested the model fit. Other tests were applied for an adequate evaluation of psychometric properties and internal reliability. The main underlying proposal is the construct developed establishing a relationship between the TPM deployment and the improvement of operational performance. Findings: The questionnaire developed was validated psychometrically, was applied in 65 plants, receiving 306 questionnaires back. A ten-factor measuring model of the CSF related to TPM deployment was confirmed with different goodness of fit indexes $(\chi 2=965.69$, $\mathrm{df}=657, \mathrm{p}<0.001$; NNFI=0.951, CFI=0.957, IFI=0.957, RMSEA: 0.039); well above acceptable thresholds. The instrument shows good internal consistency (CR index ranged from 0.758 to 0.963 ), good discriminant and convergent validity (AVE's values for all subscales $>0.572$ and the Common Method Bias evaluation indicates results are not biased. Validity of the construct for the operational performance subscale is acceptable, accordingly to Cua et al., 2001; Ma Kone et al., 2001; Konecny and Thun, 2011. Though Ciudad Juarez has a thirty plus years presence of multinational companies with twin plant (maquiladora) world-class operations, some techniques, such as TPM are deployed with noticeable differences among companies. The questionnaire allowed the identification of 34 influencing factors, specifically, the CSF and best practices for the TPM effective application and measures their impact in operational performance. Application/Improvements: This enhancement of the TPM explanatory capabilities allows the companies deploying it to have a better chance of success managing TPM projects under a CSF approach and better practices focus.
\end{abstract}

Keywords: Classifier, Feature Extraction, Feature Vector, Key Frame, Shot, Training and Testing Data Set

\section{Introduction}

To maintain competitive in the global economic environment, companies need the deployment of high performance manufacturing, in which maintenance management is a key function that supports effective production operations because the increase of the maintenance function effectiveness leads to the development of key manufacturing competencies. Besides, when this maintenance function is actively driven it increases the operational effectiveness ${ }^{1}$. A strategic approach to improve the maintenance performance and competitiveness, The deployment of TPM in manufacturing organizations is recomended because its implementation reduces customer complaints and inventory levels $\underline{2}^{2}$, increases the rate of production quality, improves deliv-

*Author for correspondence 
ery time, morale and safety, contributing to a better level of sales and profitability ${ }^{3-6}$. Nonetheless, several studies indicates that the implementation of TPM has been flawed and questionable results have been obtained ${ }^{7-9}$. Also, it has been reported that less than $10 \%$ of companies that tried to implement TPM were successful $\frac{10}{}$, although there is a contradiction because successful implementations have also been reported $\frac{11,12}{1}$.

Although there is considerable literature available devoted to the identification of the CSF for the effective implementation of TPM, this body of knowledge is very broad and shows a lack of agreement among experts. One finds several points of view regarding the factors related to the TPM's success $\frac{13-18}{}$ or failure $1 \frac{8,19-22}{}$. It is also worth noticing that there are papers about the management factors, while other papers consider technical factors. Another unfinished issue is the integration of TPM with other methodologies or world class strategies, or just the development of technological and scientific aspects as a support for the deployment of TPM. Finally, little is known about the CSF related to the effective implementation of TPM within the context of the maquiladora industry in Mexico.

The competitiveness of the twin plant industry is of utmost importance to the Mexican industrial planning due to its economic contribution. The industry has transformed Mexico into one of the world's top 10 manufacturing countries ${ }^{9}$. In 2006, the maquiladora industry employed close to 1.3 million workers ${ }^{23}$, with an average of 4 percentage points above total industrial growth. In 2000 the TP output reached $\$ 83$ billion, which is half of the total exports of Mexico. The concept of Twin Plant (TP) means that the plant in Mexico is like another one located in the United States of America. In Mexico, there are more than 2,800 TP's, and $13.5 \%$ of them are located in Juare ${ }^{24}$. Initially, in the 1970's, most of the production processes were of assembly of low aggregated value, contrasting with the high tech production of present times. Thus, one important concern for the TP industry is the conservation of the industrial equipment because their overall effectiveness is necessary for consistent product quality at an acceptable cost. For these reasons, the present study attempts to bridge the gap in research about the CSF related to the effective implementation of TPM within the context of the TP industry in Mexico. Thereby, it provides a theoretical as well as a practical tool for research related to the CSF for the TPM implementation.
The remaining part of this study is structured as follows. The second section is devoted to the review of the literature about key TPM elements, links between TPM and other strategies, and state of the art CSF studies related to implementation of TPM. Additionally, the relationships between TPM and operational performance were also reviewed. In the next subsection, methods are presented, followed by the proposed research hypotheses. The results are presented in the third section. Finally, conclusions and limitations of this study are discussed and the recommendations for future research are suggested.

\section{Literature Survey}

This section presents several TPM topics, beginning with the basic concepts of TPM, followed by a discussion of the relationship between MPT and other improvement initiatives; the theory of manufacturing strategy (MS), as a reference framework, and the relationships with lean manufacturing (LM) and with the innovation and technological development strategy (I\&TD). The relationships between TPM and Competitiveness are also discussed. Finally, the CSF's obtained in the literature review are listed along with the CFS-I-TPM instrument developed for the study. This review has the purpose of explaining the constructs that underlay the scale.

\section{TPM Basics}

Intensified competition in the global economy, the threat of global competition, the search for profitability ${ }^{25}$, the changing market demands, and rapid technological developments ${ }^{26,27}$ exert strong pressures on organizations which drive the implementation of initiatives to increase productivity, such as Lean Manufacturing and Six Sigma. Because of these pressures and the pursuit of competitiveness, companies are forced to improve organizational performance ${ }^{4}$ through the development of core manufacturing competencies $\frac{28,29}{}$, which are a source of savings and competitive advantage $\mathrm{e}^{21}$.

$\mathrm{In}^{30}$ report that TPM is a strategy developed as a response to the companies' demands of cost and quality imposed by their competitive markets. To accomplish those goals, TPM maximizes the equipment effectiveness ${ }^{\underline{6}}$ by establishing a productive maintenance system, the implementation by various departments (engineering, production, and maintenance), the full employee involve- 
ment, and productive maintenance promotion through autonomous activities performed by small groups, all with the purpose of improving the equipment effectiveness ${ }^{31}$. When TPM is effectively managed organizations achieve superior performance and can be highly competitive $\frac{1,32}{1}$.

There are many studies in the literature about the relationship between TPM and other improvement approaches such as Total Quality Management, Just in Time, Six Sigma, and Lean Manufacturing $\frac{33,34}{}$. Although the reported applications are numerous $\frac{35}{}$, the achievements and the implementation process are questionable. $\mathrm{In}^{\frac{36}{6}}$ argue that an organization must first implement the TQM because this reduces the TPM implementation time; while ${ }^{37}$ report that when the improvement begins with TPM, the operational performance is better than when TPM is applied concurrently with TQM, this could be explained because the TPM is a subset of TQM Regarding to the Just in Time (JIT) approach, in ${ }^{\underline{6}}$ argue that the operational performance is better when TPM is implemented first. On the other hand, in $\frac{38}{3}$ reported that organizations applying concurrently TPM, JIT, and TQM achieve higher operational performance indicators. Moreover, ${ }^{39}$ contribute to this controversy because they recommend implementing simultaneously TPM with SS to improve the operational performance indicators. In this sense, to Shah and Lean Manufacturing ${ }^{40}$ is integrated by several approaches such as JIT, Quality Systems, Cellular Manufacturing, Work Teams, and TPM. This constitutes a reasonable theory that is open to question.

\section{Relationship between Strategies and TPM}

There are two levels of integration between Manufacturing Strategy (MS) and the Innovation and Technological Development Strategy (I\&TDS) with TPM. The First level is called strategic level and the second level is designated as tactical level. From the strategic level, the Competitive Strategy (CS) is deployed through the MS and the I\&TDS, driving the development of technology, specifically, the design and development of product and process technologies, so their technical features represent a source of competitive advantage41, including the development of soft technologies such as TPM. In this sense 42,43 argued that innovation is a competitive priority because innovation and technological projects drive the development of production technologies, such as the TPM. From the tactical level perspective, TPM has been applied to improve the technical features of the equipment and to develop core manufacturing competencies ${ }^{44}$ and has been utilized to improve organizational performance ${ }^{45}$. Thus, tactically, the TPM can be considered as a means to deploy the MS and I\&TDS, and its effectiveness depends on the consistency between the MS and the manufacturing practices. From this discussion, it can be concluded that there is some ambiguity in the relationship of the strategies and the TPM. It is clear that the process of implementation of the TPM should be studied with a scientific approach to increase the explanatory power of the theory associated with the factors for its successful deployment.

It is known that results obtained by the deployment of a plan can be modeled by a predictive relationship, meaning that results are not obtained directly in a cause and effect relationship because the plan is deployed through a series of steps that extend in time and under multifactor causality. In this type of models the identification of the factors is important to explain their relative contribution to effectiveness in order to obtain the results desired. This predictor type relationship links TPM with operational effectiveness, as reported $\frac{35,36,46}{}$, being financial results the preferred measure of effectiveness ${ }^{47}$, although TPM effectiveness needs to be measured by cost, quality, delivery time, and flexibility ${ }^{48}$. This is very important because the improvements and measurements of these operational effects lead to the successful implementation of TPM and to the effectiveness of the production system. This situation constitutes the opportunity to investigate the factors that impact the operational performance under the paradigm of the CSF. In the next section, the Critical Success Factors identified in the literature review are presented. This discussion is the background of the proposed construct.

A considerable body of empirical evidence suggests that TPM implementation improves the competitive performance of the company, but it has been measured in various ways across the world, probably because TPM has a wide range of quantitative and qualitative performance effects. Among the quantitative effects, to $\frac{38}{6}$ TPM improves manufacturing performance through the increase in the indicators of quality, price, delivery, and flexibility, agreeing with $\frac{37.46}{4}$ in the sense that TPM has a positive and significant relationship with low cost, high levels of 
quality, and strong delivery performance. Among the qualitative performance, in ${ }^{2}$ report that TPM aids on the long-term development of six manufacturing competencies in Indian manufacturing organizations: competitive and market related competences, strategic competences, technological competences, organizational competences, operational competences, and human resource competencies. While in Malaysia, in ${ }^{3}$ reported several tangible and intangible gains such as good impression to customers about the company, the product quality and reliability, a healthy working environment for employees, management and suppliers, improvements of manpower skills, and a zero defects vision. In this study, the operational performance variables that were used are based $\frac{46,37}{}$ with a qualitative approach because TPM has quantitative and qualitative performance effects, which are most suitable for the development of an operational performance subscale for the instrument.

\section{CSF related to the Successful Application of TPM}

Through the review of the TPM literature, a set of 29 factors related to the successful implementation of TPM was constructed. However, some authors consider them as CSF while others do not make such precision. These factors are classified into three categories: management factors, technical factors, and integration factors. These factors are summarized in Tables 1 to 3 .

There are three main reasons for assigning a high importance to the factors listed in Table 1 . The main reason is the extensive and frequent use by researchers. They also are important because they may explain the effective planning and execution of TPM and we consider them important because they can be applied in the TPM routines in the maquiladora industry.

Several studies have examined the positive relationships or correlations between TPM and other initiatives such as TQM, JIT, and LM. For example, in ${ }^{49}$ argue that continuous improvement is significantly and positively related to the maintenance performance. Their findings advocate the important merge of quality management practices into maintenance processes. In addition, $\frac{50}{r e c}-$ ommend the combination of Six Sigma practices into the TPM framework to promote continuous improvement in production systems. Also, the 5's technique is considered as a key pillar of TPM $\frac{31,51-53}{}$. Therefore, Table 2 lists studies related to the integration category.

To achieve the desired results when TPM is deployed, several studies recommend applying certain tools related to the theory of maintenance (i.e. Preventive Maintenance, Autonomous Maintenance, and Reliability Centered Maintenance) besides those related to engineering design ${ }^{54}$. Moreover, other studies recommend the use of appropriate indicators to support learning, continuous improvement, and monitoring and control performance and to help identify performance gaps ${ }^{1,15}$. Additionally, this system of performance indicators should be managed with the use of information technologies ${ }^{47}$ and mobile devices for data collection ${ }^{\frac{55}{5}}$. To sum up, this maintenance framework is equivalent to the CSF related to technical aspects, which are summarized in Table 3.

Table 1. CSF related to management

\begin{tabular}{|l|l|}
\hline \multicolumn{1}{|c|}{ Identified factor } & \multicolumn{1}{c|}{ References } \\
\hline Commitment of senior management & $\underline{3,4,5,8,17,54,57,58,71,72,73}$ \\
\hline $\begin{array}{l}\text { Deployment proactive maintenance } \\
\text { policy }\end{array}$ & $\underline{4,60}$ \\
\hline $\begin{array}{l}\text { Corporate Planning / Implementation } \\
\text { plan }\end{array}$ & $\underline{5,8,14,16,17,47,74,75,76,77}$ \\
\hline Leadership of top management & $\underline{17,47,59,72}$ \\
\hline Process awareness / Communication & $\underline{5,8,14,57,72}$ \\
\hline $\begin{array}{l}\text { Effective selection of the } \\
\text { implementation team }\end{array}$ & $\underline{57,72}$ \\
\hline Gradual introduction of MPT & $\underline{57,59}$ \\
\hline Aligning organizational goals with MPT & $\underline{8,58,77}$ \\
\hline $\begin{array}{l}\text { Resources allocation (financial, human, } \\
\text { time, reward system) }\end{array}$ & $\underline{8,14,16,58,76}$ \\
\hline Implementing a feedback system & $\underline{37,54}$ \\
\hline $\begin{array}{l}\text { Integration of all employees / Teamwork } \\
\text { / Cooperation }\end{array}$ & $\underline{5,8,37,58,59,72,75,77,78}$ \\
\hline
\end{tabular}

Table 2. CSF related to integration

\begin{tabular}{|c|c|}
\hline Identified factor & References \\
\hline $\begin{array}{c}\text { Apply an improvement process } \\
\text { approach / Integration with TQM- } \\
\text { Lean-JIT }\end{array}$ & $\underline{4,30,37,47,60,79,80,81}$ \\
\hline 5'S Implementation & $\underline{82,83}$ \\
\hline
\end{tabular}


Table 3. CSF related to the technical category

\begin{tabular}{|l|l|}
\hline \multicolumn{1}{|c|}{ Identified factor } & \multicolumn{1}{c|}{ References } \\
\hline $\begin{array}{l}\text { Implementation of a maintenance } \\
\text { management computerized system / } \\
\text { Information Technology }\end{array}$ & $\underline{47,75,78}$ \\
\hline Preventive maintenance routines & $\underline{4,82,84}$ \\
\hline $\begin{array}{l}\text { Implement a maintenance reliability- } \\
\text { centered program }\end{array}$ & $\underline{57,84,85}$ \\
\hline $\begin{array}{l}\text { Full implementation of Maintenance } \\
\text { tools or Engineering Design tools }\end{array}$ & $\underline{54,60,77,79,86}$ \\
\hline Use of performance indicators & $\underline{60,15,59}$ \\
\hline Distribution plant for maintenance & $\underline{60}$ \\
\hline Development of a specific structure & $\underline{8,57,77}$ \\
\hline Using mathematical models & $\underline{87,88}$ \\
\hline Training on autonomous maintenance & $\underline{4,14,15,57,60,59,82,16,37,17,}$ \\
\hline
\end{tabular}

\section{Methods}

This study is a cross-sectional study for the development and test of a theory-based instrument to measure the CSF that influences the effective implementation of TPM. A questionnaire was constructed with the factors determined through an extensive literature research; the questionnaire was tested, corrected, and applied to a sample and the information gathered is analyzed with several statistical tests, as it is explained in the next sections.

\section{Design, Procedure, and Sample}

Prior to the application of the questionnaire, a pilot study was carried out and it revealed that scales were easily understood by the targeted participants. Also, a letter was included along with the questionnaires to explain the purpose of the survey and that the participation was voluntary and anonymous. No personal information was collected with the exception of demographic data. Next, the questionnaires were distributed to appropriate personnel with knowledge related to the implementation of TPM in their respective plants. The study covered 65 different factories to which 430 questionnaires were distributed, of which 306 were received back. The response to the questionnaire was $75.4 \%$. In this study, the sample size approach recommended by ${ }^{56}$ was used, which recommends a minimum of 250 cases for the application of a
CFA with more than six constructs. Thus, the sample size requirement was satisfied.

\section{Instrument Development}

Based on the literature review, a theory-based instrument was developed (CFS-I-TPM). Next, the construct validity of the questionnaire's scales was validated by a panel of experts who have implemented successful TPM programs in their companies. The initial version of the questionnaire was composed of 42 items and 10 subscales, where the first nine scales represent Critical Success Factors and the last scale measures the improvement of the operational performance before the implementation of the TPM. Each item represents the level of implementation of the various associated practices to TPM. A five-point Likert format was used to measure each statement. Accordingly, the range of possible responses for each item of the CFS scales was determined as follows: $1=$ never, $2=$ sporadically, $3=$ frequently, $4=$ usually, and $5=$ always While, the range of possible responses for each item of the Operational Performance scale was determined as follows: $1=$ strongly disagree, $2=$ disagree, $3=$ neither agree nor disagree, $4=$ agree, and $5=$ strongly agree. The scales and their items are presented as follows:

1. Strategic Alignment, TPM Scale (SA): In this construct various activities were included related to the development of a strategic plan for the implementation of the TPM, which includes formulation of mission, strategies, and policies specific to the TPM besides the allocation of resources, the systematic evaluation of the TPM program, and the determination of time for its implementation. This construct was integrated with 11 items that were adapted or developed from diverse studies $\frac{16,17,20,47,57-59}{}$.

2. Autonomous Maintenance Scale (AM): In this scale there were two items measuring the existence of an autonomous maintenance program and the respective training in this program $20,37,47,57$.

3. Team Alignment for TPM Scale (AT): It consists of 3 items measuring the existence of a specific TPM team, with clear goals, an effective leader, and integrated to other teams. The items are adapted from Brah and Chong $\underline{47}$.

4. Layout Promotion TPM Scale (LY): This construct consists of 2 items measuring the effective design of the facilities for production equipment and the design 
of access to promote easy maintenance of the equipment $\frac{60,61}{\text {. }}$.

5. Communication of Process of Implementation Scale (CI): It consists of 3 items measuring the actions taken by management to perform a pre-sensitization to the implementation of the TMP besides clearly communicate the progress of the system through the use and dissemination of maintenance performance indicators $\underline{5,15,47,57}$.

6. Incorporation of Cutting-Edge Technology Scale (IT): In this scale, three activities related with the incorporation of modern and sophisticated equipment to production systems were included. These items were adapted $\underline{38}$.

7. Proprietary Equipment Development Scale (PED): This construct was measured with a 3 -item scale adapted from the scale developed and tested $\underline{38}$.

8. Supplier and Customer Involvement Scale (SCI), includes some items proposed by $\underline{38}$ but they were significantly rewritten by the panel of experts. Therefore, we believe it is very different from the original scale. 5 items measure it.

9. Integration with other Practices of Continuous Improvement Scale (ICI): This construct has a relationship with the introduction of MPT as a whole or as part of the implementation of other practices of world-class such Lean Manufacturing and hard aspects of TQM. It included four items adapted ${ }^{46}$. The fifth item was inspired by the research work ${ }^{61}$.

10. Operational Performance Scale (OP): In order to measure the successful implementation of TPM, the scale proposed $\underline{37}$ was used, which included four items of perceived performance. In addition, the panel of experts included an item related to the drastic reduction of downtime.

\section{Statistical Analysis}

Prior to applying the CFA to the information collected, two statistical methods were performed. First, the Expectation Maximization Technique was used to impute missing values for the purpose of the CFA $\frac{62}{2}$. After that, Harman's one factor test and Confirmatory Factor Analysis approach $\underline{63}$ were conducted to assess the common method effects. The data in this study were self-reported and collected with a cross-sectional research design so results are not immune to common method variance, which can cause systematic measurement errors and biases to the validity of conclusions about the associations among measurements $s^{\underline{64}}$.

After excluding the effects of the common method variance, varied CFA's procedures were applied to test the model fit to empirical data as construct validity of each scale of the instrument. First, the parameters of the measurement model were estimated through the Maximum Likelihood Estimation Robust method using EQS V. $6.1^{\frac{65}{5}}$ because the data did not meet the assumptions of normality. Second, the model fit was evaluated using the raw and normalized $\chi 2$ fit statistics ${ }^{6}$, Non-normalized Fit Index (NNFI), Comparative Fit Index (CFI), Incremental Fit Index (IFI), and Root Mean Square Error of Approximations (RMSEA) described in $\frac{56}{}$. Also, the cutoff values recommended ${ }^{\underline{53}}$ for these fit indexes were applied. Next, to evaluate the convergent validity, the Average Variance Extracted (AVE) for each construct was evaluated against the rules of thumb recommended $\underline{62}$. Finally, discriminant validity was established through the AVE test ${ }^{\frac{56}{6}}, \chi^{2}$ difference test ${ }^{\frac{67}{}}$, and confidence interval between the correlation test ${ }^{608}$.

\section{Results}

The Common Method Bias was evaluated using Harman's single factor test, which determines if the majority of the variance can be explained by a single factor ${ }^{\underline{69}}$. In this model, the main axis analysis with varimax rotation revealed the presence of some distinct factors with Eigen values greater than 1.0, rather than a single factor. These factors together accounted for $69.7 \%$ of the total variance; the first factor did not account for a majority of the variance (15.37\%), thus, no general factor is apparent. Moreover, all variables (items) are loaded on one-factor to examine the fit of the CFA model. If the common method variance is largely responsible for the relationship among the variables, the one-factor CFA model should give a good fit. The CFA showed that the single-factor model did not give a good, $\chi 2=3540.984, \mathrm{p}<0.001, \mathrm{df}=702 ; \chi 2 / \mathrm{df}=5.044(>3)$; $\mathrm{CFI}=0.66$, IFI $=0.67, \mathrm{NNFI}=0.64, \mathrm{RMSEA}=0.12$. These results suggest that the common method variance was not of great concern, and thereby, is unlikely to confound the interpretation of results for this study. In order to confirm the construct validity and reliability of the factor structures for each scale of instrument, a CFA-first order (using EQS 6.1) was performed on the sample. Figure 1 illustrates the initial measurement model. 


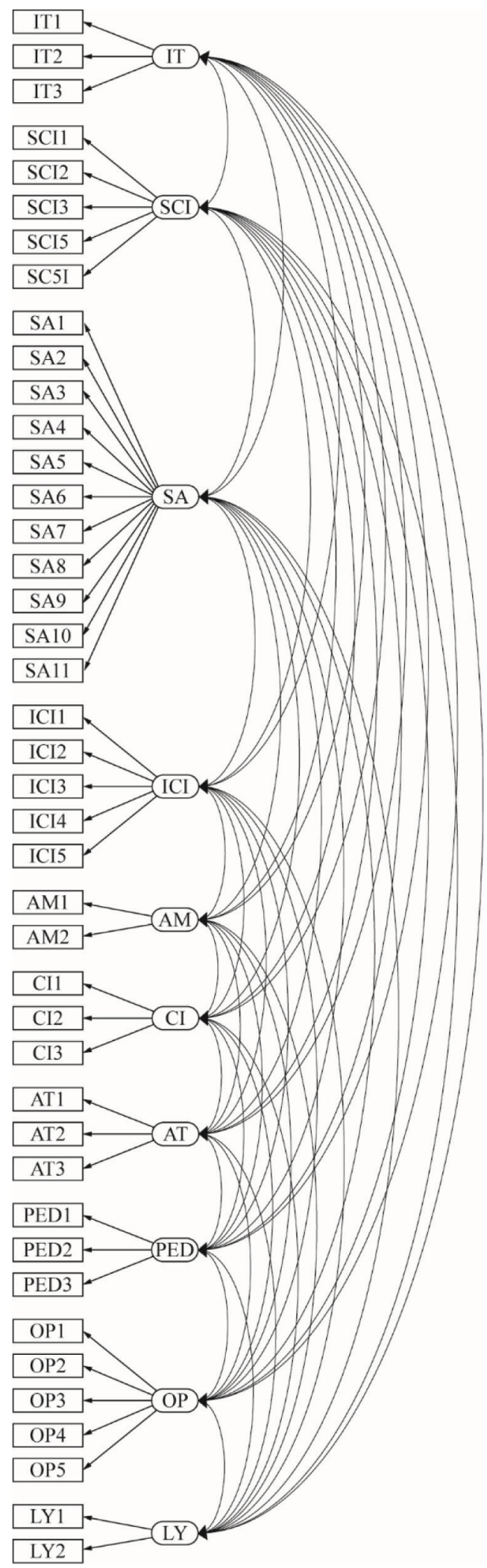

Figure 1. CFA initial model.
In the analysis of the initial model some overlapping items or high residual were detected, so items SA5, SA11, and $\mathrm{CI} 3$ were eliminated from the model. Therefore, the final version of the instrument was reduced to 39 observables variables. Newly, CFA was estimated in the final model and the results are presented in Table 4.

In conclusion, the Confirmatory Factor Analysis statistics suggesting that the model fits the observed covariance reasonably. Moreover, all values of the Composite Reliability (CR) index exceeded the recommended value of $0.70^{70}$. In addition, all items loaded significantly on their respective constructs, and the AVE of each construct, were higher than $0.50^{\frac{56}{6}}$ providing support for the convergent validity of measurement items Table 5 .

Finally, discriminant validity was supported for all constructs through three different results. First, the variance extracted for each construct was greater than its squared correlations with other constructs ${ }^{56}$.

Second, none of the $95 \%$ confidence intervals of the inter-construct correlations included in Table 6. Third, the largest correlation was identified, which was between the constructs SA and AT (0.755). Hence, a modified CFA model was evaluated fixing to 1 the covariance and a new 2 value were estimated in Table 7 .

To sum up, the $\chi^{2}$ value of the original model (965.69) was less than the value of the modified model (1180.72), and the $\chi^{2}$ difference was significant $(\mathrm{p}<0.001)$. In conclusion, the three results discussed above provide strong evidence to support the discriminant validity.

\section{Conclusions}

This is the first study about a comprehensive psychometric validation of an instrument in the Mexican maquiladora industry that measures the Critical Success Factor underlying the best practices related to the effective implementation of TPM. An Instrument with a 10-factor structure, the CSF-I-TPM scales, showed strong evidence for construct validity. In addition, the resulting 10-factor structure was confirmed as adequately fitting the data. The CSF identified into the instrument included 34 key activities that measure the effective implementation of TPM. Also, includes a scale to measure the operational performance before the TPM implementation and its construct validity was accordingly to other studies $\frac{37,38,46}{}$. On the other hand, the Common Method Bias was satis- 
Table 4. The CSF-I-TPM scale goodness-of-FIT statistics

\begin{tabular}{|c|c|c|c|c|c|}
\hline SB- $\chi 2$ & $\chi 2$ Normalized & B-B NNFI & CFI & IFI & RMSEA \\
\hline $\begin{array}{c}965.69(657 \mathrm{gl}) \\
\mathrm{p}=.000\end{array}$ & 1.470 & 0.951 & 0.957 & 0.957 & 0.039 \\
\hline $\begin{array}{c}\text { Recommended values } \\
(\text { Schreiber } \text { et al., 2006) }\end{array}$ & $<3$ & $>0.95$ & $>0.95$ & $>0.95 \quad 0.034-0.044)$ & $<0.06$ \\
UL of IC<0.08 \\
\hline
\end{tabular}

Normalized $\chi^{2}$ : $\chi 2$ /df; B-B NNFI: Bentler and Bonett's Non-normed Fit Index; CFI: Bentler's Comparative Fit Index; IFI: Bollen's Incremental Fit Index; RMSEA: Steiger and Lind's Root Mean Square Error of Approximations.

Table 5. Convergent validity

\begin{tabular}{|c|c|c|c|c|c|c|c|c|c|}
\hline \multirow[t]{2}{*}{ Construct } & \multirow[t]{2}{*}{ Item } & \multicolumn{3}{|c|}{ Convergent Validity } & \multirow[t]{2}{*}{ Construct } & \multirow[t]{2}{*}{ Item } & \multicolumn{3}{|c|}{ Convergent Validity } \\
\hline & & AVE & IFC & L & & & AVE & IFC & L \\
\hline Strategic Alignment of TPM & $\begin{array}{l}\text { SA1 } \\
\text { SA2 } \\
\text { SA3 } \\
\text { SA4 } \\
\text { SA6 } \\
\text { SA7 } \\
\text { SA8 } \\
\text { SA9 } \\
\text { SA10 }\end{array}$ & 0.572 & 0.758 & $\begin{array}{l}0.689^{* * *} \\
0.745^{* * *} \\
0.776^{* * *} \\
0.716^{* * *} \\
0.772^{* * *} \\
0.758^{* * *} \\
0.784^{* * *} \\
0.818^{* * *} \\
0.759^{* * *}\end{array}$ & $\begin{array}{l}\text { Operational } \\
\text { Performance }\end{array}$ & $\begin{array}{l}\text { OP1 } \\
\text { OP2 } \\
\text { OP3 } \\
\text { OP4 } \\
\text { OP5 }\end{array}$ & 0.648 & 0.839 & $\begin{array}{l}0.692^{\star * \star} \\
0.771^{\star * \star} \\
0.871^{\star * \star} \\
0.871^{\star \star \star} \\
0.806^{\star * \star}\end{array}$ \\
\hline Layout to promote TPM & $\begin{array}{l}\text { LY1 } \\
\text { LY2 }\end{array}$ & 0.726 & 0.906 & $\begin{array}{l}0.829^{\star \star \star} \\
0.874^{\star \star \star}\end{array}$ & $\begin{array}{l}\text { Communication } \\
\text { of } \\
\text { Implementation } \\
\text { Process }\end{array}$ & $\begin{array}{l}\mathrm{CI} 1 \\
\mathrm{CI} 2\end{array}$ & 0.666 & 0.856 & $\begin{array}{l}0.786^{\star * *} \\
0.845^{\star * *}\end{array}$ \\
\hline $\begin{array}{l}\text { Alignment of the team for } \\
\text { TPM }\end{array}$ & $\begin{array}{l}\text { AT1 } \\
\text { AT2 } \\
\text { AT3 }\end{array}$ & 0.763 & 0.931 & $\begin{array}{l}0.907^{\star \star *} \\
0.915^{\star \star *} \\
0.794^{\star \star *}\end{array}$ & $\begin{array}{l}\text { Incorporation } \\
\text { of Cutting-Edge } \\
\text { Technology }\end{array}$ & $\begin{array}{l}\text { IT1 } \\
\text { IT2 } \\
\text { IT3 }\end{array}$ & 0.823 & 0.963 & $\begin{array}{l}0.883^{\star * *} \\
0.937^{\star * *} \\
0.901^{\star * *}\end{array}$ \\
\hline $\begin{array}{l}\text { Supplier and Customer } \\
\text { Involvement }\end{array}$ & $\begin{array}{l}\text { SCI1 } \\
\text { SCI2 } \\
\text { SCI3 } \\
\text { SCI5 } \\
\text { SCI5 }\end{array}$ & 0.627 & 0.817 & $\begin{array}{l}0.806^{\star * \star} \\
0.861^{\star * \star} \\
0.829^{\star * \star} \\
0.735^{\star * \star} \\
0.717^{\star * \star}\end{array}$ & $\begin{array}{l}\text { Integration with } \\
\text { other Practices } \\
\text { of Continuous } \\
\text { Improvement }\end{array}$ & $\begin{array}{l}\text { ICI1 } \\
\text { ICI2 } \\
\text { ICI3 } \\
\text { ICI4 } \\
\text { ICI5 }\end{array}$ & 0.584 & 0.770 & $\begin{array}{l}0.719^{* * *} \\
0.844^{* * *} \\
0.785^{\star * *} \\
0.775^{\star * *} \\
0.706^{* * *}\end{array}$ \\
\hline $\begin{array}{l}\text { Proprietary Equipment } \\
\text { Development }\end{array}$ & $\begin{array}{l}\text { PED1 } \\
\text { PED2 } \\
\text { PED3 }\end{array}$ & 0.658 & 0.848 & $\begin{array}{l}0.791^{\star * *} \\
0.787^{\star * *} \\
0.853^{\star * *}\end{array}$ & $\begin{array}{l}\text { Autonomous } \\
\text { Maintenance }\end{array}$ & $\begin{array}{l}\text { AM1 } \\
\text { AM2 }\end{array}$ & 0.649 & 0.836 & $\begin{array}{l}0.947^{\star * * *} \\
0.634^{\star * *}\end{array}$ \\
\hline
\end{tabular}

${ }^{* * *} p<0.001$

factorily evaluated, so the results presented in this paper are unlikely biased.

Therefore, the aim of this study was achieved, the instrument was developed and validated, it is adequate for the measurement of the CSF related to the TPM implementation, in the twin plant industry. The CSF are estimated with the following scales:

1. Strategic Alignment of TPM. This scale measures the development of an own plan for the implementation of the TPM, which includes explicit policies to develop long-term TPM programs, formulation of a mission to the TPM, targets, performance indicators, goals, and responsibilities. This own-plan must be aligned to corporate strategy.

2. Integration with other Practices of Continuous Improvement. This scale measures the integration of the best practices related to TQM and Lean Manufacturing to the TPM program. 
Table 6. Discriminant validity: AVE and IC tests

\begin{tabular}{|c|c|c|c|c|c|c|c|c|c|c|}
\hline Construct & IT & SCI & SA & ICI & AM & $\mathrm{AT}$ & PED & F8 & OP & LY \\
\hline IT & 0.823 & $\begin{array}{l}0.566 \\
0.738\end{array}$ & $\begin{array}{l}0.537 \\
0.717\end{array}$ & $\begin{array}{l}0.624 \\
0.776\end{array}$ & $\begin{array}{l}0.372 \\
0.608\end{array}$ & $\begin{array}{l}0.486 \\
0.690\end{array}$ & $\begin{array}{l}0.572 \\
0.736\end{array}$ & $\begin{array}{l}0.631 \\
0.795\end{array}$ & $\begin{array}{l}0.440 \\
0.632\end{array}$ & $\begin{array}{l}0.546 \\
0.746\end{array}$ \\
\hline SCI & 0.425 & 0.627 & $\begin{array}{l}0.553 \\
0.729\end{array}$ & $\begin{array}{l}0.632 \\
0.812\end{array}$ & $\begin{array}{l}0.368 \\
0.600\end{array}$ & $\begin{array}{l}0.559 \\
0.739\end{array}$ & $\begin{array}{l}0.507 \\
0.691\end{array}$ & $\begin{array}{l}0.505 \\
0.701\end{array}$ & $\begin{array}{l}0.539 \\
0.715\end{array}$ & $\begin{array}{l}0.485 \\
0.717\end{array}$ \\
\hline SA & 0.393 & 0.411 & 0.572 & $\begin{array}{l}0.594 \\
0.770\end{array}$ & $\begin{array}{l}0.450 \\
0.626\end{array}$ & $\begin{array}{l}0.479 \\
0.671\end{array}$ & $\begin{array}{l}0.687 \\
0.823\end{array}$ & $\begin{array}{l}0.488 \\
0.696\end{array}$ & $\begin{array}{l}0.413 \\
0.629\end{array}$ & $\begin{array}{l}0.576 \\
0.768\end{array}$ \\
\hline ICI & 0.490 & 0.521 & 0.465 & 0.584 & $\begin{array}{l}0.421 \\
0.665\end{array}$ & $\begin{array}{l}0.566 \\
0.776\end{array}$ & $\begin{array}{l}0.575 \\
0.771\end{array}$ & $\begin{array}{l}0.529 \\
0.709\end{array}$ & $\begin{array}{l}0.524 \\
0.700\end{array}$ & $\begin{array}{l}0.517 \\
0.729\end{array}$ \\
\hline AM & 0.240 & 0.234 & 0.289 & 0.295 & 0.649 & $\begin{array}{l}0.197 \\
0.473\end{array}$ & $\begin{array}{l}0.454 \\
0.670\end{array}$ & $\begin{array}{l}0.290 \\
0.546\end{array}$ & $\begin{array}{l}0.332 \\
0.544\end{array}$ & $\begin{array}{l}0.417 \\
0.649\end{array}$ \\
\hline CI & 0.346 & 0.421 & 0.331 & 0.457 & 0.112 & 0.666 & $\begin{array}{l}0.468 \\
0.684\end{array}$ & $\begin{array}{l}0.426 \\
0.662\end{array}$ & $\begin{array}{l}0.475 \\
0.679\end{array}$ & $\begin{array}{l}0.458 \\
0.690\end{array}$ \\
\hline AT & 0.428 & 0.359 & 0.570 & 0.453 & 0.316 & 0.332 & 0.763 & $\begin{array}{l}0.499 \\
0.703\end{array}$ & $\begin{array}{l}0.458 \\
0.670 \\
\end{array}$ & $\begin{array}{l}0.481 \\
0.697 \\
\end{array}$ \\
\hline PED & 0.508 & 0.364 & 0.350 & 0.383 & 0.175 & 0.296 & 0.361 & 0.658 & $\begin{array}{l}0.356 \\
0.560 \\
\end{array}$ & $\begin{array}{l}0.449 \\
0.677 \\
\end{array}$ \\
\hline OP & 0.287 & 0.393 & 0.271 & 0.375 & 0.192 & 0.333 & 0.318 & 0.210 & 0.648 & $\begin{array}{l}0.380 \\
0.616 \\
\end{array}$ \\
\hline LY & 0.417 & 0.361 & 0.452 & 0.388 & 0.284 & 0.329 & 0.347 & 0.317 & 0.248 & 0.726 \\
\hline
\end{tabular}

IT: Incorporation of Cutting-Edge Technology; SCI: Supplier and Customer Involvement; SA: Strategic Alignment of TPM; ICI: Integration with other Practices of Continuous Improvement; AM: Autonomous Maintenance; CI: Communication of Implementation Process; AT: Alignment of the Team for TPM; PED: Proprietary Equipment Development; OP: Operational Performance; LY: Layout promotes TPM.

Table 7. Discriminant validity: $\chi^{\underline{2}}$ Test

\begin{tabular}{|c|c|c|c|c|}
\hline CFA Model & S-B $\chi^{2}$ & Degrees of Freedom & $\left.\right|_{2,1}$ Difference & $p$ Value \\
\hline Original & 965.69 & 657 & & \\
\hline Modified & 1180.72 & 658 & 215.03 & 0.000 \\
\hline
\end{tabular}

3. Layout promotes TPM. This scale measures that the production equipment capacity is considered during the design of the facilities and the layout of the machinery to facilitate the maintenance program.

4. Autonomous Maintenance. This scale measures the implementation of a program of autonomous maintenance.

5. Alignment of the Team for TPM. This scale measures the team responsible to assure that the implementation of TPM has goals aligned with the corporate plan, and that the members have experience in TPM and possess leadership skills.

6. Supplier and Customer Involvement. This scale measures the customer's needs in terms of quality and delivery time, which have to be considered when the equipment is designed, including features requiring low maintenance and relationships with suppliers of production equipment.

7. Incorporation of Cutting-Edge Technology. This scale measures the ability of the company to incorporate 
cutting-edge technology equipment in the production system.

8. Communication of Process of Implementation. This scale measures the implementation of a system of timely information of performance in the production floor, information with easy access to workers.

9. Proprietary Equipment Development. This scale measures the ability of the company to innovate or improve existing equipment, whose maintenance features are not easily copied by competitors.

\section{Limitations and Recommendations}

The value of the findings and contribution this paper presents, have to be considered under the limitations of the research design, as we explain in the next paragraphs.

We couldn't confirm a causality relationship because the data came from the same origin and through a crosssectional source, besides the variables were measured at the same time. Nonetheless, both, the Harman's one factor test and the single factor confirmatory factor analysis indicate that findings are, reasonably, free of the bias related to the measurements and the conclusions validity is maintained. Also, it is not possible to discard that data collected by questionnaires might be influenced by some response bias, $\mathrm{in}^{\underline{64}}$ suggest that generally, the measurements of perceptions is not a significant source of bias. Because the sample of this study was obtained from employees of the maquiladora industry in Juarez, Mexico, the findings cannot be generalized to all organizations.

The implications and conclusions of this study apply in the twin plant industry, although, is suggested the replication of this study in different contexts to test the generality of the findings. Also is convenient the development of other constructs not included in this study to gain a better understanding about the organizational context for the effective industrial practice of TPM. Regardless of the limitations mentioned above, this paper provides important theoretical implications for TPM theory and contributes to the literature with this identification of the Critical Success Factors related to implementation of TPM. Furthermore, to practitioners, the findings give several insights because the CFS-I-TPM instrument may assist management to make better decisions to deploy TPM.

\section{Acknowledgement}

We would like to express our gratitude to the Consejo Nacional de Ciencia y Tecnología (CONACyT) and the Asociación de Maquiladoras A.C. (AMAC) for the invaluable support that made possible this project.

\section{References}

1. Muchiri P, Pintelon L, Gelders L, Martin H. Development of maintenance function performance measurement framework and indicators. International Journal of Production Economics. 2011 May; 131(1):295-302. Crossref

2. Ahuja IPS, Khamba JS. Assessment of contributions of successful TPM initiatives towards competitive manufacturing. Journal of Quality in Maintenance Engineering. 2008; 14(4):356-74. Crossref

3. Ahmed S, Hassan MH, Taha Z. TPM can go beyond maintenance: excerpt from a case implementation. Journal of Quality in Maintenance Engineering. 2005; 11(1):19-42. Crossref

4. Ahuja IPS, Khamba JS. Total productive maintenance: literature review and directions. International Journal of Quality Reliability Management. 2008; 25(7):709-56. Crossref

5. Park KS, Han SW. TPM - Total Productive Maintenance: Impact on competitiveness and a framework for successful implementation. Human Factors and Ergonomics in Manufacturing Service. 2001; 11(4):321-38. Crossref

6. Thomas F, Goetzfried M, Basu P. Analysis of the implementation of total productive maintenance, total quality management, and just-in-time in pharmaceutical manufacturing. Journal of Pharmaceutical Innovation. 2010; 5(4):181-92. Crossref

7. Ahuja IPS, Khamba JS. Total productive maintenance: Literature review and directions. International Journal of Quality \& Reliability Management. 2008; 25(7):709-56. Crossref

8. Bamber CJ, Sharp JM, Hides M. Factors affecting successful implementation of total productive maintenance: a UK manufacturing case study perspective. Journal of Quality in Maintenance Engineering. 1999; 5(3):162-81. Crossref

9. Dowlatshahi S. The maquiladora industry and equipment maintenance: An industry-based perspective. Production Planning and Control. 2009; 20(3):227-41. Crossref

10. The right ingredients for a successful TPM or Lean implementation [Internet]. [cited 2015 Jan 18]. Available from: www.tpmonline.com.

11. Brown T. United Front, Works Management. Findlay Publications Ltd; 2010. p. 14-16. PMCid:PMC2909925 
12. Horan M. All-round improvements. Works Management Findlay Publications Ltd; 2007. p. 18-21.

13. Chlebus E, Helman J, Olejarczyk M, Rosienkiewicz M. A new approach on implementing TPM in a mine - A case study. Archives of Civil and Mechanical Engineering. 2015; 15(4):873-84. Crossref

14. Eti MC, Ogaji SOT, Probert SD. Implementing total productive maintenance in Nigerian manufacturing. Industries Applied Energy. 2004; 79:385-401. Crossref

15. Ferrari E, Pareschi A, Regattieri A, Persona A. TPM: situation and procedure for a soft introduction in Italian factories. The TQM Magazine. 2002; 14(6):350-58. Crossref

16. Graisa M, Al-Habaibeh A. An investigation into current production challenges facing the Libyan cement industry and the need for innovative Total Productive Maintenance (TPM) strategy. Journal of Manufacturing Technology Management. 2011; 22(4):541-58. Crossref

17. Lazim HM, Ramayah T. Maintenance strategy in Malaysian manufacturing companies: A Total Productive Maintenance (TPM) approach. Business Strategy Series. 2010; 11(6):38796. Crossref

18. Shen CC. Discussion on key successful factors of TPM in enterprises. Journal of Applied Research and Technology. 2015; 13:425-7. Crossref

19. Ahmed S, Hassan MH, Taha Z. State of implementation of TPM in SMIs: A survey study in Malaysia Journal of Quality in Maintenance Engineering. 2004; 10(2):93-106.

20. Ahuja IPS, Khamba JS. Strategies and success factors for overcoming challenges in TPM implementation in Indian manufacturing industry. Journal of Quality in Maintenance Engineering. 2008; 14(2):123-47. Crossref

21. Chen L, Meng B. The Three-stage method for Chinese enterprises to deploy TPM. Management Science and Engineering. 2011; 5(1):51-8.

22. Rolsfen M, Langeland C. Successful maintenance practice through team autonomy. Employee Relations. 2012; 34(3):306-21. Crossref

23. Fierro JO. Proveeduría nacional a la industria maquiladora en México: Un reto tecnológico. Frontera Norte. 2007; 19(38):191-217.

24. INEGI Estadísticas de la industria maquiladora de exportación Censo económico 2004, Instituto Nacional de Estadística, Geografía e Informática, México; 2006.

25. Pintelon L, Pinjala SK, Vereecke A. Evaluating the effectiveness of maintenance strategies. Journal of Quality in Maintenance Engineering. 2006; 12(1):7-20. Crossref

26. Adner R, Kapoor R. Innovation ecosystems and the pace of substitution: Re-examining technology S-curves. Strategic Management Journal. 2016; 37(4):625-48. Crossref

27. Ahuja IPS, Khamba JS. An evaluation of TPM implementation initiatives in an Indian manufacturing enterprise- Journal of Quality in Maintenance Engineering. 2007; 13(4):338-52. Crossref

28. Meybodi ZM. The links between just-in-time practices and alignment of benchmarking performance measures. The TQM Journal. 2015; 27(1):108-21. Crossref

29. Theodorou P, Florou G. Manufacturing strategies and financial performance-The effect of advanced information technology: CAD/CAM systems. Omega. 2008; 36(1):10721. Crossref

30. Teeravaraprug J, Kitiwanwong K, Sae TN. Relationship model and supporting activities of JIT, TQM and TMP. Journal of Science and Technology. 2011; 33(1):101-6.

31. Nakajima S. Introduction to TPM: Total Productive Management Productivity Press Portland; 1988.

32. Gupta P, Vardhan S. Optimizing OEE, productivity and production cost for improving sales volume in an automobile industry through TPM: A case study. International Journal of Production Research. 2016; 54(10):2976-88. Crossref

33. Singh K, Ahuja IS. An evaluation of transfusion of TQMTPM implementation initiative in an Indian manufacturing industry. Journal of Quality in Maintenance Engineering. 2015; 21(2):134-53. Crossref

34. Wakchaure VD, Nandurkar KN, Kallurkar SP, Gadalla MA. A conceptual framework for effective implementation of integrated manufacturing practices. ASME International Manufacturing Science and Engineering Conference; 2015. p. 14. Crossref

35. Bruun P, Mefford RN. Lean Production and Internet International Journal of Production. Economics. 2004; 89:247-60

36. Al-Hassan K, Chan JF, Metcalfe AV. The role of total productive maintenance in business excellence. Total Quality Management. 2000; 11(4-6):S596-601. Crossref

37. Konecny PA, Thun JH. Do it separately or simultaneouslyAn empirical analysis of a conjoint implementation of TQM and TPM on plant performance. International Journal of Production Economics. 2011; 133:496-504. Crossref

38. Cua KO, McKone KE, Schroeder RG. Relationships between implementation of TQM, JIT, and TPM and manufacturing performance. Journal of Operations Management. 2001; 19:675-94. Crossref

39. Thomas A, Gareth L. Developing a SME-based integrated TPM-Six Sigma strategy. International Journal of Six Sigma and Competitive Advantage. 2007; 3(3):228-47. Crossref

40. Shah R, Ward PT. Lean manufacturing: Context, practice bundles, and performance. Journal of Operations Management. 2003; 21:129-49. Crossref

41. Martinez-Berumen HA, Escobar-Toledo CE. Decisionmaking in new technologies for public research centers: a methodological proposal with systems approach. Systems Research Forum. 2011; 5:53-72. Crossref 
42. Dangayach, GS Deshmukh, SG. Implementation of manufacturing strategy: a select study of Indian process companies Production Planning Control: The Management of Operations. 2006; 12(1):89-105.

43. Gyampah-Amoako K, Acquaah M. Manufacturing strategy, competitive strategy and firm performance: An empirical study in a developing economy environment. International Journal of Production Economics. 2008; 111:575-92. Crossref

44. Avella L, Fernandez E, Vazquez CJ. Analysis of manufacturing strategy as an explanatory factor of competitiveness in the large Spanish industrial firm. International Journal of Production Economics. 2001; 72:139-57. Crossref

45. Rho BH, Park K, Yu YM. An international comparison of the effect of manufacturing strategy-implementation gap on business performance. International Journal of Production Economics. 2001; 70:89-97. Crossref

46. McKone KE, Schroeder RG, Cua KO. The impact of total productive maintenance practices on manufacturing performance. Journal of Operations Management. 2001; 19:39-58. Crossref

47. Brah SA, Chong WK. Relationship between total productive maintenance and performance. International Journal of Production Research. 2004; 42(12):2383-401. Crossref

48. Swanson L. Linking maintenance strategies to performance. International Journal of Production Economics. 2001; 70:237-44. Crossref

49. Maletic D, Maletic M, Gomiscek B. The relationship between continuous improvement and maintenance performance. Journal of Quality in Maintenance Engineering. 2012; 18(1):30-41. Crossref

50. Harsej F, Yusof SM. Continuous Improvement through an Integrated Maintenance Model. Contemporary Engineering Sciences. 2011; 4(8):353-62.

51. Steinbacher HR, Steinbacher NL. TPM for America. Productivity Press, Portland; 1993.

52. Shirose K. Total Productive Maintenance: New implementation program in fabrication and assembly industries. Japan Institute of Plant Maintenance. Tokyo; 1996.

53. Schreiber JB, Stage FK, King J, Nora A, Barlow EA. Reporting structural equation modeling and confirmatory factor analysis results: A review. The Journal of Educational Research. 2006; 99(6):323-37. Crossref

54. McAdam R, McGeough F. Implementing total productive maintenance in multi-union manufacturing organization: overcoming job demarcation. Total Quality Management. 2000; 11(2):187-97. Crossref

55. Thun JH. Supporting total productive maintenance by mobile devices. Production Planning Control. 2008; 19(4):430-4. Crossref
56. Hair JF, Black WC, Babin BJ, Anderson RE. Multivariate Data Analysis 7th Edition Pearson Prentice Hall, Cornell; 2010.

57. Chan FTS, Lau HCW, Ip RWL, Chan HK, Kong S. Implementation of Total Productive Maintenance: A case study. International Journal of Production Economics. 2005; 95:71-94. Crossref

58. Cooke FL. Implementing TPM in plant maintenance: some organizational barriers. Journal of Quality in Maintenance Engineering. 2000; 17(9):1003-16. Crossref

59. Fredendall LD, Patterson JW, Kennedy WJ, Griffin T. Maintenance modeling, its strategic impact. Journal of Managerial Issues. 1997; 9(4):440-53.

60. Carannante $\mathrm{T}$, Haigh $\mathrm{RH}$, Morris DS. Implementing total productive maintenance: A comparative study of the UK and Japanese foundry industries. Total Quality Management.1996; 7(6):605-11. Crossref

61. Soni PK. Total Productive Maintenance-An implementation experience international. Journal of Research in Engineering and Technology. 2013; 2(5):263-7.

62. Kline RB. Principles and practice of structural equation modeling. The Guilford Press. Third Edition, New York; 2011.

63. Ertürk A. The role of Person-organization Fit in TQM: Influence of values and value congruence on TQM orientation. INTECH Open Access Publisher; 2012.

64. Podsakoff PM, MacKenzie SB, Lee JY, Podsakoff NP. Common method biases in behavioral research: A critical review of the literature and recommended remedies. Journal of Applied Psychology. 2003; 88:879-903. Crossref

65. Byrne BM. Structural equation modeling With EQS basic concepts, applications, and programming, Second Edition, Lawrence Erlbaum Associates, Inc, New Jersey; 2006.

66. Jackson DL, Gillaspy JAJ, Purc-Stephenson R. Reporting practices in confirmatory factor analysis: An overview and some recommendations. Psychological Methods. 2009; 14(1):6-23. Crossref, PMid:19271845

67. Bagozzi RP, Phillips LW. Representing and testing organizational theories: A holistic construal. Administrative Science Quarterly. 1982; 27(3):459-89. Crossref

68. Anderson J, Gerbing C, David W. Structural equation modeling in practice: A review and recommended two-step approach. Psychological Bulletin. 1988; 103(3):411-23. Crossref

69. Alper E. The role of Person-organization fit in TQM: Influence of values and value congruence on TQM orientation. Quality Management and Practices. Dr Kim-Soon Ng (Ed), InTech; 2012.

70. Bagozzi RP, Youjae Y. On the evaluation of structural equation models. Journal of the Academy of Marketing Science. 1988; 16(1):74-94. Crossref 
71. Sharma RK, Kumar D, Kumar P. Manufacturing excellence through TPM implementation: A practical analysis. Industrial Management Data Systems. 2006; 106(2):256-80. Crossref

72. Lycke L. Team development when implementing TPM. Total Quality Management Business Excellence. 2003; 14(2):205-13. Crossref

73. Hansson J, Backlund F. Managing commitment: Increasing the odds for successful implementation of TQM, TPM or RCM. International Journal of Quality Reliability Management. 2003; 20(9):993-1008. Crossref

74. Alsyouf I. Measuring maintenance performance using a balanced scorecard approach. Journal of Quality in Maintenance Engineering. 2006; 12(2):133-49. Crossref

75. Chand G, Shirvani B. Implementation of TPM in cellular manufacture. Journal of Materials Processing Technology. 2000; 103:149-54. Crossref

76. Davis R. Making TPM a part of factory life, TPM Experience Project EU 1190, DTI, Findlay, sponsored by the DTI; 1997.

77. Jonsson P. The status of maintenance management in Swedish manufacturing firms. Journal of Quality in Maintenance Engineering. 1997; 3(4):233-58. Crossref

78. Bohoris GA, Vamvalis C, Tracey W, Ignatiadou K. TPM implementation in Land-Rover with the assistance of a CMMS. Journal of Quality in Maintenance Engineering. 1995; 1(4):3-16. Crossref

79. Al-Najjar B. Total quality maintenance: An approach for continuous reduction in costs of quality products. Journal of Quality in Maintenance Engineering. 1996; 2(3):4-20. Crossref

80. Finlow-Bates T, Visser B, Finlow-Bates C. An integrated approach to problem solving: Linking K-T, TQM and RCA to TPM. The TQM Journal. 2000; 12(4):284-9. Crossref

81. Muthu S, Devadasan SR, Mendonca PS, Sundararaj G. Preauditing through a knowledge base system for successful implementation of a QS 9000 based maintenance quality system. Journal of Quality in Maintenance Engineering. 2001; 7(2):90-104. Crossref

82. Friedli T, Goetzfried M, Basu P. Analysis of the implementation of Total Productive Maintenance, Total Quality Management, and Just-In-Time in Pharmaceutical Manufacturing. Journal of Pharmaceutical Innovation. 2010; 5:181-92. Crossref

83. Gnanaguru R, Puvaneswari K, Mallick J. Toyota's A3 reports for improving 6-S activities: An aeronautical industry case study International. Journal of Advanced Operations Management. 2011; 10(2):239-54. Crossref

84. Chinese D, Ghirardo G. Maintenance management in Italian manufacturing firms: Matters of size and matters of strategy. Journal of Quality in Maintenance Engineering. 2010; 16(2):156-80. Crossref

85. Ben-Daya M. You may need RCM to enhance TPM implementation. Journal of Quality in Maintenance Engineering. 2000; 6(2):82-5. Crossref

86. Blanchard BS. An enhanced approach for implementing total productive maintenance in the manufacturing environment. Journal of Quality in Maintenance Engineering. 1997; 3(2):69-80. Crossref

87. Lawrence JL. Use mathematical modeling to give your TPM implementation effort an extra boost. Journal of Quality in Maintenance Engineering. 1999; 5(1):62-9. Crossref

88. Wang FK, Lee W. Learning curve analysis in total productive maintenance. Omega. 2001; 29:491-9. Crossref

89. Parida A, Kumar U. Maintenance Performance Measurement (MPM): issues and challenges. Journal of Quality in Maintenance Engineering. 2006; 12(3):239-51. Crossref

90. Swanson L. An empirical study of the relationship between production technology and maintenance management. International Journal of Production Economics. 1997; 53(2):191-207. Crossref 